\title{
EFEKTIFITAS LEMBAR KERJA PESERTA DIDIK (LKPD) BERBASIS GUIDED DISCOVERY LEARNING PADA POKOK BAHASAN BANGUN RUANG SISI DATAR KELAS VIII SMP NEGERI 1 BENGKULU TENGAH
}

\author{
Ulva Dwi Valencia ${ }^{1}$, Syafdi Maizora ${ }^{2}$, Agus Susanta $^{3}$ \\ ${ }^{123}$ Program Studi Pendidikan Matematika JPMIPA FKIP Universitas Bengkulu \\ Email : ${ }^{1}$ ulvadwivalencia@gmail.com, ${ }^{2}$ syafdiichiemaizora@unib.ac.id, ${ }^{3}$ agusunib@yahoo.com
}

\begin{abstract}
Abstrak
Penelitian ini bertujuan untuk mengetahui tingkat efektifitas dari Lembar Kerja Peserta Didik (LKPD) berbasis Guided Discovery Learning pada Pokok Bahasan Bangun Ruang Sisi Datar Kelas VIII SMP Negeri 1 Bengkulu Tengah yang telah dikembangkan. Penelitian ini adalah penelitian pengembangan (Research and Development) dengan mengadopsi prosedur 4-D yaitu tahap pendefinisian (define), tahap perancangan (design), dan tahap pengembangan (develop). Pada tahap pengembangan dilakukan uji efektifitas. Uji efektifitas Lembar Kerja Peserta Didik (LKPD) dilakukan pada kelas VIII.8 SMP Negeri 1 Bengkulu Tengah semester genap tahun ajaran 2017/2018 berjumlah 31 orang peserta didik. Instrumen penelitian ini adalah lembar efektifitas LKPD. Hasil penelitian menunjukan bahwa LKPD berbasis guided discovery learning pada pokok bahasan bangun ruang sisi datar kelas VIII SMP Negeri 1 Bengkulu Tengah termasuk dalam kategori sangat efektif dengan skor rata-rata 4,55 dengan pencapaian efektifitas: (a) Aktivitas peserta didik dalam kegiatan balajar sangat efektif dengan skor rata-rata 4,31; (b) Respon peserta didik terhadap pembelajaran sangat efektif dengan skor rata-rata 4,4; (c) Hasil belajar peserta didik kelas VIII.8 SMP Negeri 1 Bengkulu Tengah sangat efektif dengan skor rata-rata 4,84 dan rata-rata jumlah peserta didik yang mencapai nilai ketuntasan minimal 75 yaitu $90,32 \%$.
\end{abstract}

Kata kunci : Efektifitas, Penelitian Pengembangan, Lembar Kerja Peserta Didik (LKPD), Guided Discovery Learning

\begin{abstract}
This research was aimed to know the level of effectiveness from Student's Worksheet (LKPD) based on Guided Discovery Learning of Three Dimention at the Second Grade of SMP Negeri 1 Bengkulu Tengah. This research was the development research by adopting 4-D procedures that consisted of defining, designing, and developing. The development of initial product was conducted by effectiveness test. The effectiveness of student's worksheet (LKPD) was tried out to thirty one students of second grade SMP Negeri 1 Bengkulu Tengah in second semester of academic year of 2017/2018. The instrumen of this research was effectiveness sheet of student's worksheet (LKPD). The result of student's worksheet developing showed Student's Worksheet (LKPD) based on Guided Discovery Learning of Three Dimention at the Second Grade of SMP Negeri 1 Bengkulu Tengah was in very effective with mean score 4,55 that the effectiveness consisted of: (a) The student's activity in learning was very effective with mean score 4,31; (b) The student's response in learning was very effective with mean score 4,4; (c) The learning outcomes of second grade students of SMP Negeri 1 Bengkulu Tengah was very effective with mean score 4,84 and the mean of students that passed the minimum score 75 was $90,32 \%$.
\end{abstract}

Keyword : Efectiveness, Research Development, Student's Worksheet (LKPD), Guided Discovery Learning

Ulva, Syafdi, Agus

Efektifitas Lembar Kerja Peserta Didik (Lkpd) berbasis Guided Discovery Learning pada Pokok Bahasan Bangun Ruang Sisi Datar Kelas VIII SMP Negeri 1 Bengkulu Tengah 


\section{PENDAHULUAN}

Matematika merupakan alat untuk mengembangkan cara berfikir (Hudojo (2005: 37). Matematika merupakan salah satu mata pelajaran wajib lulus ketika peserta didik menempuh ujian nasional (UN), mulai dari jenjang sekolah dasar (SD), sekolah menengah pertama (SMP), sampai sekolah menengah atas (SMA). Oleh sebab itu, sangat penting bagi peserta didik mampu menguasai materi pelajaran matematika, salah satunya yaitu pokok bahasan bangun ruang sisi datar. Dengan menguasai materi pelajaran, diharapkan peserta didik dapat mencapai tujuan pembelajaran.

Untuk mencapai tujuan pembelajaran, peserta didik membutuhkan proses pembelajaran yang bermakna. Menurut Ausubel (1963) dalam Gazali (2016: 183) pembelajaran bermakna merupakan proses mengaitkan informasi atau materi baru dengan konsep-konsep yang telah ada dalam struktur kognitif. Berdasarkan hasil wawancara pada 10 januari 2018 dengan guru matematika kelas VIII SMP Negeri 1 Bengkulu Tengah, diketahui bahwa kurikulum yang digunakan adalah kurikulum 2013. Pembelajaran menggunakan buku teks matematika edisi revisi 2017. Pada pokok bahasan bangun ruang sisi datar guru biasanya menggunakan metode diskusi berbantuan LKPD, akan tetapi LKPD tersebut belum maksimal karena hanya memuat permasalahan dan soal latihan, sehingga belum memuat langkah-langkah yang dapat membantu peserta didik untuk menemukan suatu konsep yang dimulai dari pemberian rangsangan yang dapat memicu peserta didik mencoba menyelesaikan permasalahan dan akhirnya menemukan konsep. Oleh karena itu, diperlukan LKPD yang dapat membantu proses pembelajaran yang memuat langkah-langkah yang menuntun peserta didik menemukan suatu konsep melalui penemuan yang dilakukan.

Menurut Diknas (2004) dalam Prastowo ( 2015: 203) lembar kegiatan siswa (student work sheet) adalah lembaran-lembaran berisi tugas yang harus dikerjakan oleh peserta didik. Selanjutnya menurut Prastowo (2015: 204)
LKPD yaitu bahan ajar cetak berupa lembarlembar kertas yang berisi materi, ringkasan, dan petunjuk-petunjuk pelaksanaan tugas pembelajaran yang harus dikerjakan oleh peserta didik, yang mengacu pada kompetensi dasar yang harus dicapai. Berdasarkan uraian tersebut, maka LKPD dapat dijadikan pedoman agar peserta didik dapat melakukan kegiatan secara aktif dan mandiri dalam pembelajaran serta membantu mengarahkan peserta didik untuk mengkonstruksi pengetahuan yang telah dipelajari untuk menemukan suatu konsep matematika ataupun menyelesaikan suatu permasalahan.

Cogne dalam Illahi (2012: 92) mengemukakan bahwa guided discovery merupakan pembelajaran dengan sistem dua arah yaitu melibatkan peserta didik dalam menjawab pertanyaan pendidik sementara pendidik membimbing peserta didik kearah yang tepat. Selanjutnya, menurut Sani (2015: 97), guided discovery learning atau pembelajaran penemuan terbimbing merupakan metode yang digunakan untuk membangun konsep dibawah pengawasan guru. Pembelajaran guided discovery learning merupakan metode pembelajaran kognitif yang menuntut guru lebih kreatif menciptakan situasi yang dapat membuat peserta didik belajar aktif menemukan pengetahuan sendiri.

Arends dalam Aqib dan Murtadlo (2016: 337) mengemukakan sintaks penemuan terbimbing (guided discovery) terdiri dari 5 fase sebagai berikut :

1. Menyampaikan tujuan, mengelompokkan, dan menjelaskan prosedur discovery.

2. Pendidik menyampaikan suatu masalah

3. Peserta didik memperoleh data eksperimen

4. Peserta didik membuat hipotesis dan penjelasan

5. Analisis proses penemuan

Penelitian ini dilakukan untuk mengembangkan perangkat pembelajaran berupa Lembar Kerja Peserta Didik (LKPD) berbasis guided discovery learning. Efektifitas Lembar Kerja Peserta Didik (LKPD) pada pokok bahasan bangun ruang sisi datar dengan

Ulva, Syafdi, Agus

Efektifitas Lembar Kerja Peserta Didik (Lkpd) berbasis Guided Discovery Learning pada Pokok Bahasan Bangun Ruang Sisi Datar Kelas VIII SMP Negeri 1 Bengkulu Tengah 
LKPD yang mengadaptasi langkah-langkah guided discovery learning.

Berdasarkan latar belakang yang telah dikemukakan di atas, maka rumusan masalah yang akan dikaji dalam penelitian ini adalah bagaimana tingkat efektifitas dari Lembar Kerja Peserta Didik (LKPD) berbasis guided discovery learning pada pokok bahasan bangun ruang sisi datar.

Adapun tujuan penelitian ini adalah untuk mengetahui tingkat efektifitas dari Lembar Kerja Peserta Didik (LKPD) berbasis guided discovery learning pada pokok bahasan bangun ruang sisi datar yang telah dikembangkan.

\section{METODE}

Jenis penelitian yang dilakukan adalah penelitian pengembangan (Research and Development). Metode penelitian dan pengembangan (Research and Development) adalah metode penelitian yang digunakan untuk menghasilkan produk tertentu, dan menguji keefektifan produk tersebut (Sugiyono, 2017: 297). Penelitian ini menggunakan model pengembangan 4-D yang dikembangkan oleh Thiagarajan, Semmel, dan Semmel (1974) dalam Trianto (2011: 93), model ini terdiri dari 4 tahap yaitu pendefinisian (define), perancangan (design), pengembangan (develop) dan penyebaran (desseminate). Penelitian ini hanya terbatas sampai tahap pengembangan (develop).

Subjek dalam penelitian pengembangan Lembar Kerja Peserta Didik (LKPD) berbasis guided discovery learning pada pokok bahasan bangun ruang sisi datar adalah peserta didik SMP Negeri 1 Bengkulu Tengah kelas VIII. Pada tahap uji efektifitas diujicobakan pada kelas VIII.8 yang berjumlah 31 orang peserta didik yang memiliki karakteristik kemampuan belajar matematika yang heterogen yakni berkemampuan sedang, rendah, dan tinggi.

Instrumen yang digunakan dalam penelitian ini adalah lembar efektifitas LKPD yang terdiri dari lembar pengamatan aktivitas peserta didik, lembar angket respon peserta didik, dan hasil belajar peserta didik. Teknik pengumpulan data yang dilakukan dalam penelitian ini adalah pengumpulan keefektifan LKPD. Teknik analisis data yang digunakan adalah analisis efektifitas LKPD yang diperoleh melalui data nilai pengamatan aktivitas peserta didik dalam pembelajaran, respon peserta didik terhadap LKPD, dan hasil belajar 31 orang peserta didik kelas VIII.8 yang mengujicoba LKPD pada tahap efektifitas.

Skor rata-rata aktivitas peserta didik dihitung dengan menggunakan rumus :

$$
\bar{A}=\frac{\sum_{j=1}^{n} \bar{A}_{i}}{n}
$$

(Rumus Rata-rata Hitung Dimodifikasi dari Sudjana, 1975)

Keterangan :

$\bar{A}_{\text {Peserta didik }}$

$\bar{A}_{i}$

$n$

: Skor rata-rata aktivitas peserta didik

: Skor rata-rata aktivitas peserta didik aspek ke-i

: Banyaknya aspek

Skor rata-rata respon peserta didik dihitung menggunakan rumus:

$$
\bar{R}=\frac{\sum_{j=1}^{n} \bar{R}_{i}}{n}
$$

(Rumus Rata-rata Hitung Dimodifikasi dari Sudjana, 1975)

Keterangan:

$\bar{R} \quad$ : Skor rata-rata respon peserta didik

$\bar{R}_{i} \quad:$ Skor rata-rata respon peserta didik ke-i

$n \quad$ : Banyak peserta didik

Skor rata-rata hasil belajar peserta didik diperoleh dari 30\% nilai pengerjaan LKPD dan $70 \%$ nilai pengerjaan Tes Hasil Belajar (THB). Rata-rata hasil belajar peserta didik diperoleh dengan menggunakan rumus:

$\bar{H}_{i}=\left(\frac{\sum L K P D}{N_{1}} \times 30 \%\right)+\left(\frac{\sum T H B}{N_{2}} \times 70 \%\right)$ Keterangan: $\bar{H}_{i}$ peserta didik ke-i

$\sum L K P D \quad$ : Jumlah nilai pengerjaan LKPD 
$\sum T H B \quad:$ Jumlah nilai pengerjaan THB

$N_{1} \quad$ : Jumlah LKPD

$N_{2} \quad$ : Jumlah THB

Setelah itu dilakukan pemberian nilai rata-rata efektifitas menggunakan rumus:

$\bar{E}=\frac{(\bar{A} \times 30 \%)+(\bar{R} \times 30 \%)+(\bar{H} \times 40 \%)}{100 \%}$

(Rumus rata-rata efektifitas diadaptasi dari Maizora, 2011)

$\bar{E} \quad$ : Skor rata-rata efektifitas

$\bar{A} \quad$ : Skor rata-rata hasil aktivitas

$\bar{R} \quad$ : Skor rata-rata respon peserta didik

$\bar{H} \quad$ : Skor rata-rata hasil belajar peserta didik

Selanjutnya nilai skor rata-rata efektifitas dicocokkan dengan Kriteria Pengkategorian Keefektifan LKPD yang dimodifikasi dari Widoyoko (2017: 238) berikut.

Tabel 1 Kriteria Pengkategorian Keefektifan LKPD

\begin{tabular}{|c|c|}
\hline Interval Skor & Kategori Keefektifan \\
\hline $\bar{E} \leq 1,8$ & Tidak Efektif \\
\hline $1,8<\bar{E} \leq 2,6$ & Kurang Efektif \\
\hline $2,6<\bar{E} \leq 3,4$ & Cukup Efektif \\
\hline $3.4<\bar{E}<4.2$ & Efektif \\
\hline
\end{tabular}

\section{HASIL DAN PEMBAHASAN}

Hasil penelitian ini diperoleh dari uji efektifitas Lembar Kerja Peserta Didik (LKPD).

\section{Uji Efektifitas}

Uji efektifitas dilakukan untuk melihat keefektifan LKPD. Uji efektifitas dilakukan terhadap 31 orang peserta didik kelas VIII.8 SMP Negeri 1 Bengkulu Tengah yang sedang mendapatkan materi tentang bangun ruang sisi datar. Hasil uji efektifitas memberikan data berupa aktivitas dalam kegiatan belajar mengajar yang terdiri dari aktivitas peserta didik dalam proses pembelajaran, respon peserta didik terhadap LKPD, dan hasil belajar peserta didik yang diambil dari $30 \%$ nilai pengerjaan LKPD dan $70 \%$ nilai Tes Hasil Belajar (THB) peserta didik. Hasil uji efektifitas dapat dilihat pada tabel 2 berikut.

Tabel 2. Hasil Uji Efektifitas

\begin{tabular}{|l|c|c|}
\hline \multicolumn{1}{|c|}{ Analisis } & $\begin{array}{c}\text { Skor } \\
\text { Rata-rata }\end{array}$ & Kriteria \\
\hline $\begin{array}{l}\text { Aktivitas } \\
\text { peserta didik }\end{array}$ & 4,31 & $\begin{array}{l}\text { Sangat } \\
\text { Efektif }\end{array}$ \\
\hline $\begin{array}{l}\text { Respon peserta } \\
\text { didik }\end{array}$ & 4,4 & $\begin{array}{l}\text { Sangat } \\
\text { Efektif }\end{array}$ \\
\hline $\begin{array}{l}\text { Hasil Belajar } \\
\text { Peserta Didik }\end{array}$ & 4,84 & $\begin{array}{l}\text { Sangat } \\
\text { Efektif }\end{array}$ \\
\hline $\begin{array}{l}\text { Skor Rata-Rata } \\
\text { Uji Efektifitas }\end{array}$ & 4,55 & $\begin{array}{l}\text { Sangat } \\
\text { Efektif }\end{array}$ \\
\hline
\end{tabular}

Berdasarkan analisis data yang diperoleh terlihat bahwa aktivitas peserta didik termasuk dalam kategori sangat efektif dengan skor rata-rata 4,31. Berdasarkan skor yang diperoleh tersebut dapat disimpulkan bahwa secara keseluruhan aktivitas peserta didik pada proses pembelajaran sudah baik menurut pengamatan aktivitas peserta didik oleh pengamat. Adapun aktivitas yang dilakukan peserta didik pada saat pembelajaran yaitu aktivitas pertama peserta didik mencermati tujuan pembelajaran, duduk berdasarkan kelompok yang telah dibagi pendidik dan memahami prosedur guided discovery. Aktivitas kedua yaitu peserta didik memperhatikan permasalahan yang disajikan pada LKPD. Aktivitas ketiga peserta didik dapat mengidentifikasi permasalahan pada LKPD. Aktivitas keempat yaitu setiap kelompok peserta didik berdiskusi dan berusaha mengumpulkan data yang dapat membantu untuk menyelesaikan permasalahan seperti pada gambar berikut.

Ulva, Syafdi, Agus

Efektifitas Lembar Kerja Peserta Didik (Lkpd) berbasis Guided Discovery Learning pada Pokok Bahasan Bangun Ruang Sisi Datar Kelas VIII SMP Negeri 1 Bengkulu Tengah 


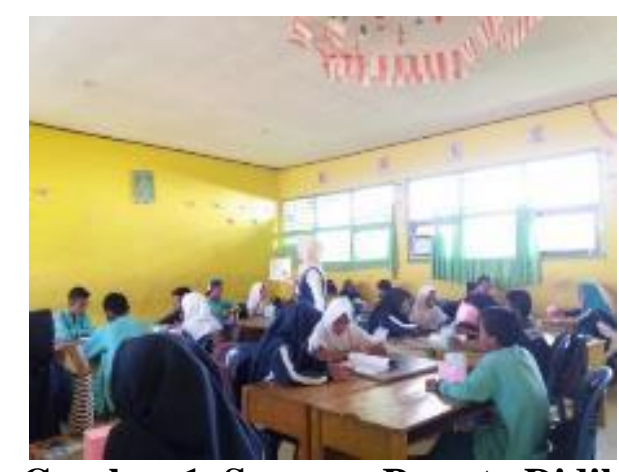

Gambar 1. Suasana Peserta Didik Berdiskusi saat Mengumpulkan Data

Selanjutnya aktivitas kelima yaitu peserta didik mampu membuat hipotesis (perkiraaan) jawaban dari permasalahan. Aktivitas keenam yaitu peserta didik mampu menguji hipotesis dan memverifikasi apakah data yang telah ditemukan dapat memecahkan permasalahan, sehingga dari aktivitas keenam peserta didik dapat melakukan aktivitas ketujuh yaitu peserta didik mampu menyimpulkan materi pembelajaran berdasarkan langkahlangkah kegiatan LKPD dan dapat menerapkan konsep yang diperoleh dengan dapat mengerjakan soal latihan. Pada saat proses pembelajaran peserta didik terlihat mengajukan pertanyaan apabila mengalami kesulitan dan guru membimbing peserta didik.

Respon peserta didik termasuk dalam kategori sangat efektif dengan skor rata-rata 4,4. Hal ini menunjukkan bahwa peserta didik memberikan respon yang baik terhadap pembelajaran menggunakan LKPD yang dikembangkan. Berdasarkan angket respon yang diisi oleh peserta didik, rata-rata peserta didik memberikan penilaian "setuju" dan "sangat setuju", hanya paling banyak 2 orang peserta didik yang memberikan penilaian "cukup setuju" dan paling banyak 1 orang yang memberikan penilaian "kurang setuju" pada aspek "LKPD dapat membantu dan mendorong saya untuk aktif dalam pembelajaran", sehingga dapat disimpulkan bahwa pembelajaran menggunakan LKPD dapat memotivasi peserta didik dalam belajar matematika, memahami materi, menemukan konsep, menerapkan sintaks guided discovery learning, membantu peserta didik untuk aktif dalam pembelajaran, dan merasa senang belajar matematika dengan adanya LKPD.

Nilai hasil belajar peserta didik diperoleh dari 30\% nilai pengerjaan LKPD dan $70 \%$ nilai pengerjaan THB yang dilaksanakan di pertemuan kelima setelah 4 kali pertemuan menggunakan LKPD. Soal THB terdiri dari 6 soal esai. LKPD yang diterapkan kepada peserta didik pada saat proses pembelajaran mempunyai pengaruh terhadap kemampuan pemahaman peserta didik pada pokok bahasan bangun ruang sisi datar. Hal ini dapat dilihat dari jawaban-jawaban peserta didik pada lembar tes hasil belajar soal nomor satu seperti gambar berikut.

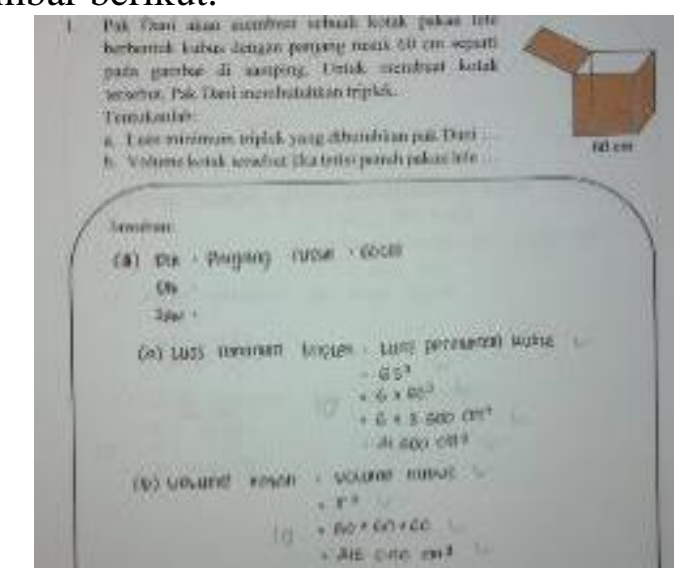

\section{Gambar 2. Jawaban THB Peserta Didik Soal Nomor 1}

Soal nomor satu merupakan soal yang konsepnya dibahas pada proses pembelajaran LKPD 1 dan LKPD 3. Pada LKPD 1 peserta didik menemukan konsep luas permukaan kubus dan balok sedangkan pada LKPD 3 peserta didik menemukan konsep volume kubus dan balok, sehingga jawaban dari peserta didik pada soal nomor satu tersebut telah sesuai dengan konsep yang telah ditemukan peserta didik pada LKPD 1 dan LKPD 3. Peserta didik dapat menyelesaikan permasalahan yang ada pada soal nomor 1. Hal ini cukup memperlihatkan bahwa LKPD mempunyai pengaruh terhadap jawaban benar peserta didik. Secara umum berdasarkan jawaban peserta didik pada lembar tes hasil belajar, peserta didik sudah mengerti konsep akan tetapi pada proses pengerjaannya peserta didik masih kurang teliti dalam menghitung sehingga

Ulva, Syafdi, Agus

Efektifitas Lembar Kerja Peserta Didik (Lkpd) berbasis Guided Discovery Learning pada Pokok Bahasan Bangun Ruang Sisi Datar Kelas VIII SMP Negeri 1 Bengkulu Tengah 
jawaban masih salah. Berikut ini contoh jawaban peserta didik yang kurang teliti dalam menghitung.

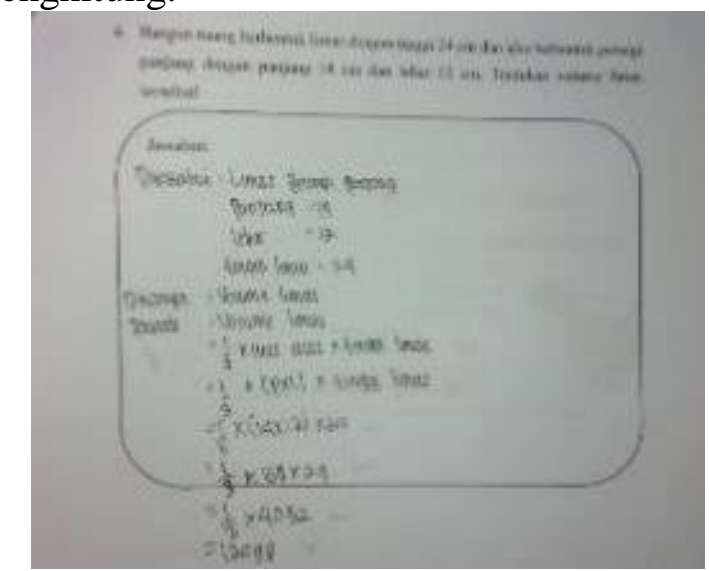

\section{Gambar 3 Contoh Jawaban THB Peserta Didik yang Kurang Teliti}

Sehingga berdasarkan nilai pengerjaan LKPD dan THB diperoleh skor hasil belajar peserta didik yaitu 4,84 dengan kriteria sangat efektif dan persentase peserta didik yang mencapai nilai ketuntasan minimal 75 yaitu $90,32 \%$. artinya peserta didik telah mampu menerapkan konsep yang diperoleh pada proses pembelajaran dengan menggunakan LKPD sehingga mencapai kompetensi yang telah ditentukan.

Selanjutnya berdasarkan data aktivitas peserta didik, respon peserta didik, dan hasil belajar peserta didik, diperoleh tingkat efektifitas Lembar Kerja Peserta Didik (LKPD) yaitu dengan skor rata-rata efektifitas 4,55 yang termasuk dalam kategori sangat efektif. Hal ini menunjukkan bahwa Lembar Kerja Peserta Didik (LKPD) berbasis guided discovery learning dapat memaksimalkan aktivitas, respon, dan hasil belajar peserta didik, sehingga LKPD memberikan manfaat pada proses pembelajaran dan layak digunakan dengan melakukan beberapa perbaikan atau revisi menyesuaikan saran dan masukan dari peserta didik maupun guru sehingga menghasilkan media pembelajaran final.

\section{PENUTUP}

\section{Kesimpulan}

Lembar Kerja Peserta Didik (LKPD) berbasis guided discovery learning pada pokok bahasan bangun ruang sisi datar kelas VIII SMP Negeri 1 Bengkulu Tengah termasuk dalam kategori sangat efektif dengan skor ratarata 4,55 karena:

a. Aktivitas peserta didik dalam kegiatan balajar sangat efektif dengan skor rata-rata 4,31 .

b. Respon peserta didik terhadap pembelajaran sangat efektif dengan skor rata-rata 4,4 .

c. Hasil belajar peserta didik kelas VIII.8 SMP Negeri 1 Bengkulu Tengah sangat efektif berdasarkan penilaian LKPD dan Tes Hasil Belajar (THB) dengan skor ratarata 4,84 dan telah mencapai persentase ketuntasan klasikal yaitu 90,32\%.

\section{Saran}

Saran-saran yang dapat diberikan penulis adalah sebagai berikut:

a. Pengembangan LKPD sebaiknya dibuat sesuai dengan tingkat pengetahuan pengguna, menggunakan bahasa yang sederhana, dan memperhatikan pemilihan kata yang tepat serta tidak berbelit-belit yang membuat pengguna LKPD sulit memahami.

b. Hendaknya untuk pengembangan LKPD selanjutnya agar membuat desain LKPD yang lebih menarik, perhatikan kombinasi warna LKPD sehingga LKPD menjadi lebih menarik.

\section{DAFTAR PUSTAKA}

Aqib Zainal dan Ali Murtadlo. 2016. Kumpulan Metode Pembelajaran Kreatif dan Inovatif. Bandung: Satunusa.

Hamzah \& Muhlisrarini. 2014. Perencanaan dan Strategi Pembelajaran Matematika. Jakarta: Rajagrafindo Persada.

Hudojo, Herman. 2005. Pengembangan Kurikulum dan Pembelajaran Matematika. Malang: Universitas Negeri Malang (UM Press).

Gazali, Rahmita Yuliana. 2016. Pembelajaran Matematika yang Bermakna. Math Didactic: Jurnal Pendidikan

Ulva, Syafdi, Agus

Efektifitas Lembar Kerja Peserta Didik (Lkpd) berbasis Guided Discovery Learning pada Pokok Bahasan Bangun Ruang Sisi Datar Kelas VIII SMP Negeri 1 Bengkulu Tengah 
Matematika, (online), Vol.2, No.3, (http://jurnal.stkipbjm.ac.id/index.php/ math/article/download/110/95, diakses pada 23 Desember 2017).

Illahi, Mohammad Takdir. 2012. Pembelajaran

Discovery Strategy \& Mental Vocational Skill. Jogjakarta: Diva Press.

Maizora, Syafdi. 2011. "Pengembangan Web Pembelajaran Kalkulus Differensial FKIP Universitas Bengkulu". Tesis tidak diterbitkan. Padang: Program Pasca Sarjana Universitas Negeri Padang.

Prastowo, Andi. 2015. Panduan Kreatif Membuat Bahan Ajar Inovatif Menciptakan Metode Pembelajaran yang Menarik dan Menyenangkan. Yogyakarta: Diva Press.
Sani, Ridwan Abdullah. 2015. Pembelajaran Saintifik untuk Implementasi Kurikulum 2013. Jakarta: Bumi Aksara.

Sudjana. 1975. Metoda Statistika. Bandung: Tarsito.

Sugiyono. 2017. Metode Penelitian Kuantitatif, Kualitatif dan $R \& D$. Bandung: Alfabeta.

Trianto. 2011. Model Pembelajaran Terpadu Konsep, Strategi, dan Implementasinya dalam Kurikulum Tingkat Satuan Pendidikan (KTSP). Jakarta: Bumi Aksara.

Widoyoko, Eko Putro. 2017. Evaluasi Program Pembelajaran Panduan Praktis Bagi Pendidik dan Calon Pendidik. Yogyakarta: Pustaka Pelajar. 